\title{
Study on International Indices And Instructional Leadership Style of College Principals in The Rural Context of Sindh
}

\author{
Tayyaba Zarif* \\ Abdul Nabi Gorchani** \\ Aziz Un Nisa*** \\ ABSTRACT
}

\begin{abstract}
Educational leadership is to run an educational institution with an intention to achieve better learning out comes. Principal, head teachers or masters lead schools. The way the leaders try to achieve those goals is known as a leadership style. Leadership style of public sector college principals in Pakistan has increasing popularity. This research is design to study on international indices and instructional leadership style of college principals in the rural context of Sindh. The study focused on a) school's goals and curriculum development, b) Actions to improve teachers' instruction, c) Actions to supervise teachers' instructional learning outcomes by college Principals of District Shaheed Benazirabad This research was quantitative by method and descriptive by purpose. The population of this study included college Principals (Boys/ Girls) and lecturers of colleges of District Shaheed Benazirabad. The sample of this study contained Principals and 70\% College Lecturers of District Shaheed Benazirabad Sindh, Pakistan. For sampling, simple random sampling technique is use. To compare the results of this study with the results of the OECD member and volunteer countries was a limitation for the researcher because of availability of resources as the OECD under TALIS administered tool on principals/ head teachers of lower secondary schools. The collected data analyzed in percentages, frequencies, and means. American Psychological Association (APA) style sixed edition is use for referencing. The obtained data is analyze in mean scores. The Results shows variation in the responses of the two groups on the following queries:

- whether the college principals make it sure that in their colleges, they work on goals and/or a college development plan,

- whether the college principals make it sure that the principals pay attention to disruptive behavior in classrooms,

- whether the college principals make it sure that the principals give lecturers suggestions as to how they can improve their teachings and

- Whether the college principals make it sure that the principals monitor students' the results show a bigger variance from 0.50 to 0.90 .
\end{abstract}

KEY WORDS: Leadership Style, College goals, rural context

*Shaheed Benazir Bhutto University, Shaheed Benazirabad

**Shaheed Benazir Bhutto University, Shaheed Benazirabad

*** Assistant Professor, Department of Education, University of Karachi 
Jhss, Vol. 9, No. 2 , July to December, 2018

\section{INTRODUCTION}

According to Organization of Economic and Cultural Development OECD (2009) Instructional leadership includes a) managing school goals focusing on class room instructions of the teachers to yield desired outcomes, b) Instructional management intends to enhance and improve teacher instructions in the class room, c) Direct supervision of instructions requires taking actions to supervise instructions of teachers and student learning outcomes ${ }^{1}$. These leadership aspects have also been favored in one way or other ${ }^{2}$

Leadership in every discipline plays a vital role to maintain harmony and progress. Leadership in educational institutions is to make endeavors to achieve desired educational goals. In schools, colleges and universities, leadership behaviors, practices, and actions have great impact on student learning outcomes. It can only be ascertain by within colleges that how do they lead the team towards achieving institutional goals. Leaders in leading educational institutions are under increased pressure to accomplish institutional goals, are expected to provide an instructional program for each child so that better learning can occur, and are expected to set vision for their institutions vividly to articulate goals for better changes. In literature there can be found number of leadership and management styles applied or followed by the Principals of the colleges, such as autocratic leadership, distributive leadership, instructional leadership, administrative leadership, Task Style leadership, People-Centered Style, Participatory leadership, Directing or Teamwork Styles, Free-Reign Styles, Laissez faire leadership and some others with slight addition of affixes as "leader full" etc.

The current research study intended to study International Indices and Instructional Leadership Style of College Principals in the Rural Context of Sindh. The foremost intention of the research study is to look into the International indices related to the instructional leadership style prepared by Organization of Economic and Cultural Development (OECD). Such as role of college principals in developing institutional goals and their implementation, strategies of college principals for

1. OECD. "Creating Effective Teaching and Learning EnvironmentFirst Results from TALIS. PARIS CEDEX 16, FRANCE: OECD publication,." 2009

2 Portin, B, S. "Manifestations of critical leadership in tides of reform: contradiction or opportunity? Paper presented at the Annual Meeting of the University Council for Educational Administration, Minneapolis, MN, 29-31 October." 1999

For futher information see

Bush, T. "Educational leadership and management: theory, policy, and practice ." South African Journalof Education 27, no. 3 (2007): 391-406

Lea, W. M. "Do Administrative Leadership Styles Affect Agricultural Education Teachers? The University of Tennessee, Martin." 2011

Smith, A. "Authoritarian leadership style explained." Small Business Chronicle, 2016 
evaluation of teaching methods in the class room and procedures adopted by college principals to supervise learning outcomes in the rural context of Sindh

\section{THEORETICAL FRAME WORKING}

According to the OECD's TALIS first results 2009, Principals in every country are/ have adopted "instructional leadership style, which, according to them are central paradigms of current era of effective educational institutional leadership. The prevalence of those practices vary country to country at large, such evidences are observe in Brazil, Poland, and Slovenia and such as Spain and Estonia. In TALIS countries a handful amount of school, Principals have adhered Instructional leadership styles. In majority of the countries according to the TALIS's results, the schools with Instructional leaders are mentors to teachers and counselors for professional development of teachers In majority of the TALIS countries, according to OECD' TALIS first results 2009, the principals who adhered to instructional leadership style, developed professional development programs for those teachers who were instructionally weak, (OECD, 2009)

The TALIS by the OECD gives an inner view that how internationally comparative perspective of educational systems are responding in their member and partner countries (OECD, 2009). The OECD focused on secondary and lower secondary public and private educational institutions. They examined professional development of teachers, beliefs, attitudes and practices of teachers, teacher appraisal and feedback and educational institutional leadership in 23 participating member and partner countries. Therefore, TALIS has opened a window to provide opportunity to the countries of the world to look into their own teaching practices in the light of what is happening in rest of the world countries. The new window opened by the TALIS became basis of current research study. Moreover, the researcher to applied and tested leadership indices on the College Principals of District Shaheed Benazirabad (SBA), of province Sindh, Pakistan.

\section{OBJECTIVES}

1. To study of role of college principals in developing institutional goals and their implementation.

2. To identify the strategies of college principals for evaluation of teaching methods in the classroom.

3. To study procedures adopted by college principals to supervise learning outcomes.

\section{RESEARCH QUESTIONS}

1. To what extent college principals play their role in developing goals of institution and their implementation? 
2. How many strategies college principals use for evaluation of teaching methods in the classroom?

3. To what extent the supervision procedures adopted by college principals for students learning out comes.

\section{SCOPE}

This research study in general will be helpful and beneficial for education department, College Principals, and their faculty members as to follow particular trend in college leadership. It will facilitate policy makers to plan and implement their policies related with principals in public sector colleges.

\section{JUSTIFICATION}

This research and its conclusions will focus on effective Instructional and Administrative management behaviors of college principals. The study will help to improve the current deficiencies, flaws; in actual practices in the management of colleges. Government can use predicted results for improvement of education. This study in general will be helpful and beneficial for education department, College Principals, and their faculty as well to follow particular trend in college management. It will facilitate policy makers to plan and implement their policies related with principals in public sector colleges.

\section{LITERATURE REVIEW}

The researchers differ in defining the word leadership. We find number of definitions in the literature. ${ }^{3}$ The word leader can be define as inspiring a bunch of people working in an organization or in a social construct for achieving a common goal. In an organizational setting it can simply further be defined that bringing their work place people with strategy for meeting organizational goals. ${ }^{4}$ The definition of leadership encompasses the capabilities to be able to motivate others towards a common goal. Leader is an inspiration and director of pre-set actions. ${ }^{5}$ It is observed that there are people who have natural endowment with excessive leadership qualities and proved themselves at the time of the crisis and convinced people to abide by their suggestions and act as per their instructions ${ }^{6}$. According to the Gorchani, Siyal, Jessar, \& Jamali ${ }^{7}$ the leaders have vision, mission and hope for

3 Bolden, A. What is leadership? Leadership South West Research Report 1 . University of Exeter Center for leadership studies, 2004

4 Ward, Susan. "What Is Leadership? And Can You Learn to Be a Good Leader?" 2018.

5 Ibid.,

6 Ibid.,

7 Gorchani, Abdul Nabi, Afroz Siyal, Farzana Suleman Jessar, and Noor Muhammad Jamali. "Dimensions Of Leadership And Management In Educational Institutions: A Theoretical 
people those who follow them. ${ }^{8}$ Leader is define as a person leading a group of people towards a common goal. Leader establishes a clear vision and share vision with others and makes them to follow. A leader puts him/her selves in times of the crises in front of the people. Leadership in any institution is consider an essential element of controlling process. Leadership is to get things done by their subordinates. The sub component of leadership is a body, which is required to guide and lead different organizational and institutional affairs ${ }^{9}$. Toprak, Inandi, Kolak, \& Sayman, defined the leadership style as an organizational or an institutional structure, practices and policies the leaders follow to run an institution. ${ }^{10} \mathrm{An}$ educational leadership is an individual or more than a group of people who have the charge and have to lead the educational institutions and learners towards quality education. ${ }^{11}$ It is further defined that a responsible person or group of people whose responsibility is to administer or run the school as a principal or head teacher ${ }^{12}$. The prime responsibility of the educational institutional leader as principal or head teacher or head master is to guide their teachers to improve educational process in pre-secondary, secondary and post-secondary educational institutions ${ }^{13}$. According to Nazim \& Mahmood, (2016) and Smith, Miror, Brashen, \& Remaly, (2017), an institutional leader requires to vary his or her leadership style as per the requirements of the time and situation, or as per the needs of the institution. ${ }^{14}$ Transformational leaders according to the Nazim \& Mahmood, (2016) tend to give importance to their personal development and intrinsic motivation of their subordinates for achieving institutional goals. Such type of leaders focus on setting out the requirements and aspiration of their followers along with desired results for organizational betterment. They are transformational and transactional leaders aligned with dual qualities those create positive results. According to the life cycle behavioral model developed by Hersey and Blanchard in 1969, and afterwards it got fame and now known as situational leadership, which penetrated the Idea of

And Conceptual Frame Work." Asian Journal of Management Sciences \& Education 6, no. 1 (2017): 37-46

$8 \quad$ Webpage. "Business Dictionary Definition." 2018

9 Aydin, Ayhan, Yilmaz Sarier, and Sengül UYSAL. "The Effect of School Principals' Leadership Styles on Teachers' Organizational Commitment and Job Satisfaction." Educational Sciences: Theory \& Practice - Educational Consult 13, no. 2 (2013): 806-811.

10 Toprak, Mustafa, Bulent Inandi, Ahmet Levent Kolak, and Mumtaz Sayman. "Do Leadership Styles Influence Organizational Health? A Study in Educational Organizations." International Journal of Educational Methodology (1) 1 (2018): 19 - 26.

11 Web-page. "What is Educational Leadership." 2018.

12 Ibid.,

13 Ibid.,

14 Nazim, Farheen, and Azhar Mahmood. "Principals' Transformational and Transactional Leadership Style and Job Satisfaction of College Teachers ." Journal of Education and Practice 7, no. 34 (2016). 
parenting style and the way it changed the developmental level of learners. ${ }^{15}$ Democratic leadership style encompasses the characteristics of leaders involves their subordinates in decision-making process but retain the authority of making decision. Democratic leadership style creates working harmony in their institutions and makes their subordinates responsible for performance and learning outcome ${ }^{16}$. According to the Smith, Miror, Brashen, \& Remaly, an authoritative leader or a leader with autocratic behavior keeps control over their sub-ordinates through strict rules, guidelines, and threatening of negative consequences if not obeyed by their followers. ${ }^{17}$ According to the OECD, (2009), the instructional leaders have three prime functions such as, management for school goals, instructional management - actions to improve teachers' instructions, and direct supervision of instructions in the school - actions to directly supervise teachers' instructions and learning outcomes. ${ }^{18}$

According to OECD goals Principals having high scores on TALIS index are frequent in taking actions to manage educational affairs in educational institutions in accordance with institutional goals with direct observation and emphasis to ensure that teachings of the faculty in the class room is in accordance with pre-set institutional goals so that those can be achieved. Such heads of the educational institutions too intend to consider learner's performance, achievements, and exam results to reset school goals and suggest developments in curriculum. Such Principals make efforts to make it sure that there is clarity within institution about the responsibility for coordinating the curriculum. Principals high on this index according to OECD (2009) make it sure that professional development activities of the teachers are in line with institutional goals and curricular objectives. According to OECD, (2009) Principals high on this index pay a meaningful amount of their managerial time in endeavoring to improve classroom instructions. On average according to the OECD (2009) principals in 10 countries including Denmark, Malta and Brazil, are above the TALIS mean, and principals of 10 countries including Malaysia, Estonia and the Slovak Republic, are below the mean of TALIS scores. According to the (OECD, 2009) Principals with high on index are the one who directly supervise the instructions and learning outcomes of teaching faculty in the

15 Hersey, P., \& Blanchard, K. H. "Great ideas revisited: Revisiting the life-cycle theory of leadership." Training \& Development Journal 50, no. 1 (1996): 42.

16 Hawkinson, E. "Team teaching and situational leadership theory: Adapting and combining frameworks for Japanese English Education." US-China Education Review 6, no. 3 (2016): 183-189.

\section{For futher information see}

Dampson, Dandy George, Felicia Mensah Havor, and Prince Laryea. "Distributed Leadership an Instrument for School Improvement: The Study of Public Senior High Schools in Ghana." Journal of Education and e-Learning Research, 5, no. 2 (2018): 79-85.

17 Smith, Gina, Maria Miror, Henry Brashen, and Kristie Remaly. "Successful Instructional Leadership Styles In Education." Journal of Instructional Research 6 (2017).

18 Op.Cit., OECD 
educational institution, and also make frequent suggestions to teaching faculty to how to bring up instructions in the classrooms and monitor academic efforts and work of the students.

\section{RESEARCH METHODOLOGY}

This research study was quantitative by method and descriptive. The persons consulted for this research study were principals and lecturers of the public sector colleges of District Shaheed Benazirabad. The sample of this research study were the principals and 70 percent College Lecturers. For sampling simple random sampling techniques is use. A modified tool was use with prior permission (from OECD) on five point Likert scale. The data is analyze in mean scores.

\section{DATA ANALYSIS}

Means of the variables and difference of means of two group responses.

\begin{tabular}{|c|c|c|c|c|}
\hline S. No: & Table No: & Respondents & Mean & $\begin{array}{l}\text { Mean } \\
\text { variance }\end{array}$ \\
\hline \multirow[t]{2}{*}{$1 \mathrm{a}$} & \multirow{2}{*}{$\begin{array}{l}\text { "Professional development } \\
\text { activities of" lecturers "are in } \\
\text { accordance with the teaching } \\
\text { goals of the" college. }\end{array}$} & College Principals & 4.30 & \multirow[t]{2}{*}{0.33} \\
\hline & & College Lecturers & 3.97 & \\
\hline \multirow[t]{2}{*}{$2 a}$. & \multirow{2}{*}{$\begin{array}{l}\text { Lecturers "work according to the } \\
\text { college's "educational goals. }\end{array}$} & College Principals & 4.14 & \multirow[t]{2}{*}{0.03} \\
\hline & & College Lecturers & 4.11 & \\
\hline \multirow[t]{2}{*}{ 3a. } & \multirow{2}{*}{$\begin{array}{l}\text { Student performance results to } \\
\text { develop the" college's } \\
\text { "educational goals". }\end{array}$} & College Principals & 4.14 & \multirow[t]{2}{*}{0.10} \\
\hline & & College Lecturers & 4.04 & \\
\hline \multirow[t]{2}{*}{$4 a}$. & \multirow{2}{*}{$\begin{array}{l}\text { Exam results into account in } \\
\text { decisions regarding curriculum } \\
\text { development. }\end{array}$} & College Principals & 3.86 & \multirow[t]{2}{*}{0.09} \\
\hline & & College Lecturers & 3.77 & \\
\hline \multirow[t]{2}{*}{$5 a}$. & \multirow{2}{*}{$\begin{array}{l}\text { There is clarity concerning the } \\
\text { responsibility for coordinating } \\
\text { the curriculum". }\end{array}$} & College Principals & 4.00 & \multirow[t]{2}{*}{1.33} \\
\hline & & College Lecturers & 2.67 & \\
\hline \multirow[t]{2}{*}{$6 a}$. & \multirow{2}{*}{$\begin{array}{l}\text { We work on goals and/or a } \\
\text { college development plan. }\end{array}$} & College Principals & 4.43 & \multirow[t]{2}{*}{0.98} \\
\hline & & College Lecturers & 3.45 & \\
\hline \multirow[t]{2}{*}{$7 b}$. & \multirow{2}{*}{$\begin{array}{l}\text { When a lecturer has problems in } \\
\text { his/her classroom, "I take the } \\
\text { initiative to discuss matters". }\end{array}$} & College Principals & 4.71 & \multirow[t]{2}{*}{0.51} \\
\hline & & College Lecturers & 4.20 & \\
\hline \multirow[t]{2}{*}{$8 \mathrm{~b}}$. & \multirow{2}{*}{$\begin{array}{l}\text { Inform lecturers "about } \\
\text { possibilities for updating their }\end{array}$} & College Principals & 4.29 & \multirow[t]{2}{*}{0.29} \\
\hline & & College Lecturers & 4.00 & \\
\hline
\end{tabular}




\begin{tabular}{|c|c|c|c|c|}
\hline & knowledge and skills". & & & \\
\hline \multirow[t]{2}{*}{ 9b. } & \multirow{2}{*}{$\begin{array}{l}\text { When a lecturer "brings up a } \\
\text { classroom problem, we solve the } \\
\text { problem together". }\end{array}$} & College Principals & 4.60 & \multirow[t]{2}{*}{0.30} \\
\hline & & College Lecturers & 4.30 & \\
\hline \multirow[t]{2}{*}{$10 \mathrm{~b}}$. & \multirow{2}{*}{$\begin{array}{l}\text { Pay attention to disruptive } \\
\text { behavior in classrooms". }\end{array}$} & College Principals & 4.60 & \multirow[t]{2}{*}{0.70} \\
\hline & & College Lecturers & 3.90 & \\
\hline \multirow[t]{2}{*}{$11 \mathrm{c}}$. & \multirow{2}{*}{$\begin{array}{l}\text { Observe instruction in } \\
\text { classrooms. }\end{array}$} & College Principals & 3.85 & \multirow[t]{2}{*}{0.16} \\
\hline & & College Lecturers & 3.69 & \\
\hline \multirow[t]{2}{*}{ 12c. } & \multirow{2}{*}{$\begin{array}{l}\text { Give lecturers "suggestions as to } \\
\text { how they can improve their } \\
\text { teaching". }\end{array}$} & College Principals & 4.43 & \multirow[t]{2}{*}{0.76} \\
\hline & & College Lecturers & 3.67 & \\
\hline \multirow[t]{2}{*}{$13 c}$. & \multirow[t]{2}{*}{ I monitor students' work. } & College Principals & 4.43 & \multirow[t]{2}{*}{0.81} \\
\hline & & College Lecturers & 3.62 & \\
\hline \multirow[t]{2}{*}{$14 \mathrm{c}}$. & \multirow{2}{*}{$\begin{array}{l}\text { Check to see whether classroom } \\
\text { activities are in keeping with our } \\
\text { educational goals. }\end{array}$} & College Principals & 4.29 & \multirow[t]{2}{*}{0.27} \\
\hline & & College Lecturers & 4.02 & \\
\hline
\end{tabular}

The statement that whether the college principals make it sure that the professional development activities of lecturers are in accordance with the teaching goals of their colleges, the mean score results of college principals is 4.30 and the mean score of College Lecturers is 3.97, showing mean variance of 0.33 .

The statement that whether the college principals make it sure that the lecturers work according to the college's educational goals, the mean score results of college principals is 4.14 and the mean score of College Lecturers is 4.11 , showing a least mean variance of 0.3 .

The statement that whether the college principals make it sure to use student performance results to develop the college's educational goals, the mean score results of college principals is 4.14 and the mean score of College Lecturers is 4.04, showing a least mean variance of 0.10 .

The statement that whether the college principals take exam results into account in decisions regarding curriculum development, the mean score results of college principals is 3.86 and the mean score of College Lecturers is 3.77, showing a least mean variance of 0.09 .

The statement that whether the college principals make to ensure that there is clarity concerning the responsibility for coordinating the curriculum, the mean score results of college principals is 4.00 and the mean score of College Lecturers is 2.67 , showing a least mean variance of 0.09 .

On the statement that whether the college principals make it sure that in their colleges, they work on goals and/or a college development plan, the mean score 
results of college principals is 4.43 and the mean scores of College Lecturers is 3.45, showing a least mean variance of 0.98 .

On the statement that whether the college principals make it sure that when a lecturer has problems in his/her classroom, the principals take initiative to discuss those matters for their better solutions with them, the mean score results of college principals is 4.71 and the mean scores of College Lecturers is 4.20 , showing a least mean variance of 0.51 .

On the statement that whether the college principals make it sure that they inform lecturers about possibilities for updating their knowledge and skills, the mean score results of college principals is 4.29 and the mean scores of College Lecturers is 4.00, showing a least mean variance of 0.29 .

On the statement that whether the college principals make it sure that when a lecturer brings up a classroom problem, they solve that problem together, the mean score results of college principals is 4.60 and the mean scores of College Lecturers is 4.30 , showing a least mean variance of 0.30 .

On the statement that whether the college principals make it sure that the principals pay attention to disruptive behavior in classrooms, the mean score results of college principals is 4.60 and the mean scores of College Lecturers is 3.90 , showing a mean variance of 0.70 .

On the statement that whether the college principals make it sure that the principals observe instructions in the classrooms, the mean score results of college principals is 3.85 and the mean scores of College Lecturers is 3.69, showing a least mean variance of 0.16 .

On the statement that whether the college principals make it sure that the principals give lecturers suggestions as to how they can improve their teachings, the mean score results of college principals is 4.43 and the mean score of College Lecturers is 3.67 , showing a mean variance of 0.76 .

On the statement, that whether the college principals make it sure that the principals monitor students' work, the mean score results of college principals is 4.43 and the mean score of College Lecturers is 3.62 , showing a mean variance of 0.81 .

On the statement that whether the college principals make it sure that the college principals check to see whether classroom activities are in keeping with their educational goals, the mean score results of college principals is 4.29 and the mean scores of College Lecturers is 4.02, showing a least mean variance of 0.27. 
Jhss, Vol. 9, No. 2 , July to December, 2018

\section{RESULTS OF THE RESEARCH QUESTIONS}

\begin{tabular}{|l|l|l|l|l|}
\hline $\begin{array}{l}\text { R.Q. } \\
\text { No: }\end{array}$ & Table No: & Respondents & Mean & $\begin{array}{l}\text { Mean } \\
\text { variance }\end{array}$ \\
\hline 2 & $\begin{array}{l}\text { Developing goals of institution } \\
\text { and their implementation }\end{array}$ & $\begin{array}{l}\text { College } \\
\text { Principals }\end{array}$ & 4.54 & 0.51 \\
\cline { 3 - 4 } & College Lecturers & 4.03 & \\
\hline 3 & $\begin{array}{l}\text { Strategies college principals use } \\
\text { for evaluation of teaching } \\
\text { methods in the class room }\end{array}$ & $\begin{array}{l}\text { College } \\
\text { Principals }\end{array}$ & 4.25 & 0.51 \\
\cline { 2 - 3 } & $\begin{array}{l}\text { College Lecturers } \\
\text { by college principals for students } \\
\text { learning out comes. }\end{array}$ & $\begin{array}{l}\text { College } \\
\text { Principals }\end{array}$ & 3.98 & 0.11 \\
\cline { 2 - 3 } & College Lecturers & 3.87 & \\
\hline
\end{tabular}

The results of the research question number one show the variation between the mean scores of the respondents and the mean score of the responses of the college principals, which is 4.54 . Wherein the mean score of responses of the lecturers is 4.03 and for the areas such as professional development activities of the lecturers, resonation of lecturers with college goals, student performance for developing college goals and decision making, and clarity regarding coordinating the curriculum the visible variance is 0.51 .

The results of the research question number two show the variation between the mean scores of the respondents the mean score of the responses of the college principals, which is 4.25 . Wherein the mean score of responses of the lecturers is 3.74 , the visible variance is 0.51 for the areas such as principals take initiatives when there is a problem in the classroom, information to the lecturer for their updating their knowledge and skills, solution of school problems together and paying attention towards disruptive behavior in the classroom.

Furthermore, the results of the research question two show least variation between the mean scores of the respondents the mean score of the responses of the college principals, which is 3.98. Wherein the mean score of responses of the lecturers is 3.87 and the visible variance is 0.11 for the areas such as observation of classroom instructions, suggestion to the teachers for improving teaching in the classroom, monitoring students' works and insuring that the classroom activities resonate with college educational goals. 


\section{Consolidated results on instructional leadership style.}

\begin{tabular}{|l|l|l|l|l|}
\hline S. No: & Table No: & Respondents & Mean & $\begin{array}{l}\text { Mean } \\
\text { variance }\end{array}$ \\
\hline 1 & $\begin{array}{l}\text { Instructional indices and } \\
\text { difference of means of two } \\
\text { group responses. }\end{array}$ & College Principals & 4.29 & 0.62 \\
\cline { 2 - 3 } & College Lecturers & 3.67 & \\
\hline
\end{tabular}

Regarding the mean scores on instructional leadership indices, the results show that the mean score of principals is 4.29 and the mean score of lecturers is 3.67 with mean variance of 0.67 . This do not closely resonate with each other and reveal a visible dispersion in two sample groups, which suggest that the principals may have maximum optimism while as the lecturers may have their concerns which might have resulted such variation.

\section{FINDINGS}

On the statement that whether the college principals make it sure that the professional development activities of lecturers are in accordance with the teaching goals of their colleges, that lecturers work according to the college's educational goals, whether the college principals make it sure to use student performance results to develop the college's educational goals, whether the college principals make it sure that when a lecturer has problems in his/her class room, the principals take initiative to discuss those matters for their better solutions with them, whether the college principals make it sure that they inform lecturers about possibilities for updating their knowledge and skills, whether the college principals make it sure that when a lecturer brings up a classroom problem, they solve that problem together, whether the college principals make it sure that the college principals check to see whether classroom activities are in keeping with their educational goals, the results have diversion towards strongly agreement and have little variance.

The results regarding whether the college principals take exam results into account in decisions regarding curriculum development, and whether the college principals make it sure that the principals observe instructions in the classrooms where in the results are little diverted towards agreement but with little variance as well.

The results regarding whether the college principals make it sure that in their colleges, they work on goals and/or on a college development plan, whether the college principals pay attention to disruptive behavior in classrooms, whether the college principals make it sure that they give lecturers some suggestions as to how they can improve their teachings and whether the college principals make it sure 
that the principals monitor students' the results show a bigger variance from 0.50 to 0.90 work, the mean score results, which shows disagreement on the areas between two groups of the respondents.

\section{CONCLUSION}

Based on findings the entire results show positive variance. However variation in the responses of the two groups are to be found in the questions such as whether the college principals make it sure that in their colleges they work to achieve goals and/or on a college development plan. Similarly, questions such as whether the college principals pay attention to disruptive behavior of students in classrooms, whether Principals make it sure that suggestions were given to lecturers as to how they can improve their teachings, the results show a bigger variance from 0.50 to 0.90 work, means disagreement on the areas between two groups of the respondents. 
Study on International Indices And Instructional Leadership Style Of College Principals in The Rural Context of Sindh

\section{References}

Aydin, Ayhan, Yilmaz Sarier, and Sengül UYSAL. "The Effect of School Principals' Leadership Styles on Teachers' Organizational Commitment and Job Satisfaction." Educational Sciences: Theory \& Practice - Educational Consult 13, no. 2 (2013): 806811

Bolden, A. What is leadership? Leadership South West Research Report 1 . University of Exeter Center for leadership studies, 2004

Bush, T. "Educational leadership and management: theory, policy, and practice ." South African Journalof Education 27, no. 3 (2007): 391-406

Dampson, Dandy George, Felicia Mensah Havor, and Prince Laryea. "Distributed Leadership an Instrument for School Improvement: The Study of Public Senior High Schools in Ghana." Journal of Education and e-Learning Research, 5, no. 2 (2018): 7985

Gorchani, Abdul Nabi, Afroz Siyal, Farzana Suleman Jessar, and Noor Muhammad Jamali. "Dimensions Of Leadership And Management In Educational Institutions: A Theoretical And Conceptual Frame Work." Asian Journal of Management Sciences \& Education 6, no. 1 (2017): 37-46

Hawkinson, E. "Team teaching and situational leadership theory: Adapting and combining frameworks for Japanese English Education." US-China Education Review 6, no. 3 (2016): 183-189

Hersey, P., \& Blanchard, K. H. "Great ideas revisited: Revisiting the life-cycle theory of leadership." Training \& Development Journal 50, no. 1 (1996): 42

Lea, W. M. "Do Administrative Leadership Styles Affect Agricultural Education Teachers? The University of Tennessee, Martin." 2011.

Nazim, Farheen, and Azhar Mahmood. "Principals' Transformational and Transactional Leadership Style and Job Satisfaction of College Teachers ." Journal of Education and Practice 7, no. 34 (2016)

OECD. "Creating Effective Teaching and Learning EnvironmentFirst Results from TALIS. PARIS CEDEX 16 , FRANCE: OECD publication,." 2009

Portin, B, S. "Manifestations of critical leadership in tides of reform: contradiction or opportunity? Paper presented at the Annual Meeting of the University Council for Educational Administration, Minneapolis, MN, 29-31 October." 1999 
Smith, A. "Authoritarian leadership style explained." Small Business Chronicle, 2016 Smith, Gina, Maria Miror, Henry Brashen, and Kristie Remaly. "Successful Instructional Leadership Styles In Education ." Journal of Instructional Research 6 (2017)

Toprak, Mustafa, Bulent Inandi, Ahmet Levent Kolak, and Mumtaz Sayman. "Do Leadership Styles Influence Organizational Health? A Study in Educational Organizations." International Journal of Educational Methodology (1) 1 (2018): 19 26

Ward, Susan. "What Is Leadership? And Can You Learn to Be a Good Leader?" 2018

Webpage. "Business Dictionary Definition." 2018

Web-page. "What is Educational Leadership." 2018 